\title{
Zinc Hexacyanoferrate/Multi-Walled Carbon Nanotubes Films for Rechargeable Aqueous Batteries
}

\author{
Murillo N. T. Silva, ${ }^{\oplus a}$ José D. Ardisson, ${ }^{b}$ José D. Fabris ${ }^{a, c}$ and Edson Nossol ${ }^{\circledR *, a}$ \\ ${ }^{a}$ Instituto de Química, Universidade Federal de Uberlândia, 38400-902 Uberlândia-MG, Brazil \\ ${ }^{b}$ Centro para o Desenvolvimento da Tecnologia Nuclear (CDTN), 31270-901 Belo Horizonte-MG, Brazil \\ 'Departamento de Química, Instituto de Ciências Exatas (ICEx), Universidade Federal de Minas Gerais, \\ 31270-901 Belo Horizonte-MG, Brazil
}

\begin{abstract}
Zinc hexacyanoferrate $(\mathrm{ZnHCF})$ is a Prussian Blue analog and can be intercalated by both monovalent and divalent ions. ZnHCF/multi-walled carbon nanotube (MWCNT) film could be used as a cathode for zinc ions battery. Carbon nanotubes improved significantly the electrochemical performance of the electrode. It is described the preparation of ZnHCF/MWCNT films by the interfacial method with cyclohexane/water mixture as solvent. The crystal structure, morphology, and microstructure of the as-prepared products were characterized by X-ray diffraction, scanning electron microscopy, Mossbaïer, Raman spectroscopy, and infrared spectroscopy. Results revealed that the MWCNTs extend the electrochemical properties of the ZnHCF and influence the structure and morphology of the hexacyanoferrate particles. If tested as cathode material for zinc ion batteries, the nanocomposite film exhibits a capacity of $25.81 \mathrm{~mA} \mathrm{~h} \mathrm{~g}^{-1}$, which is much higher than those obtained for a $\mathrm{ZnHCF}$ single-component film $\left(3.28 \mathrm{~mA} \mathrm{~h} \mathrm{~g}^{-1}\right)$. The physical characteristics and properties that allow good reversibility to a high potential difference, achieved with the ZnHCF/MWCNT film, suggest new developments in the manufacture of translucent, flexible and light energy storage devices, which can be used as a lower-cost, safer and environmentally friendly alternative to the currently existing technologies.
\end{abstract}

Keywords: Prussian Blue analog, aqueous battery, cathode material, storage devices, nanostructured carbon materials

\section{Introduction}

Transition metal hexacyanoferrates, commonly known as Prussian Blue analogs (PBAs), are a new class of porous crystalline hybrid materials, formed by the bridge of inorganics vertices ( $\mathrm{Fe}$ and other transition metal ions) and electron-donating ligands $(\mathrm{C} \equiv \mathrm{N})$, which exhibit outstandingly useful properties for various technological applications..$^{1-3}$ Owing to their favorable properties, such as controllable chemical, morphological and open-atomic framework structures, along with adjustable porous sizes, and high electrochemical performance, recent studies have reported their potential uses in gas storage, ${ }^{4-6}$ batteries, ${ }^{7-9}$ catalysis, ${ }^{10-12}$ energy separation, ${ }^{13}$ drug delivery, ${ }^{14-16}$ sensors and environmental cleanup. ${ }^{17-19}$

In PBAs, the involved transitions metals are usually organized in octahedral coordination, crystalizing, with some exceptions, in the cubic unit cell arrangement (space

*e-mail: enossol@ufu.br group Fm-3m). However, some zinc hexacyanoferrates (ZnHCF), containing $\mathrm{Fe}^{\mathrm{II}}$ and $\mathrm{Fe}^{\mathrm{III}}$, have been reported ${ }^{20}$ as being hexagonally coordinated systems crystallizing in the rhombohedral structure (space group R-3c), where $\mathrm{FeC}_{6}$ octahedra and $\mathrm{ZnN}_{4}$ tetrahedron are linked together by $\mathrm{C} \equiv \mathrm{N}$ ligands. Such coordination imparts a relatively high thermal stability and an interesting porous framework to these materials, as both metal centers have saturated their coordination spheres with atoms from the bridge-group $(-\mathrm{C} \equiv \mathrm{N}-)^{8,20}$

Due to its unique properties, the zeolite-like framework of ZnHCF endows the possibility of behaving as intercalation hosts for various cations. In that sense, several applications for $\mathrm{ZnHCF}$ are focused on the development of materials for energy storage devices. ZnHCF has already been reportedly ${ }^{8,21,22}$ studied as cathodic material in rechargeable aqueous metal-ion batteries (RAMB) systems, leading to the insertion of metallic ions such as $\mathrm{Na}^{+}$and $\mathrm{Zn}^{2+}$. However, no attempt to use $\mathrm{ZnHCF}$ as composites material in RAMB systems has been so far reported. 
In order to obtain better results in the performance of cathodic materials in batteries, it is proposed to use Faradaic reactions of the surface on nanostructured carbon electrodes, which can store more energy than the doublelayer capacitance on conventional capacitor electrodes and provide higher power capability. ${ }^{23}$

Among the nanostructured carbon materials, the carbon nanotubes (CNTs) have been widely used as the electrode material, due to their favorable dimensional ratio, large specific surface area, efficient charge transport, as well as good mechanical resistance and electrical conductance. In addition, the excellent softness of the material has extended its potential application for electrodes in thin-film configuration, enabling new devices to achieve transparency, flexibility and electrochromic properties. $^{24-26}$

Herein, we present the use of a new class of electrodes for zinc-ion batteries, which are based on nanocomposites thin films between $\mathrm{ZnHCF}$ and multi-walled carbon nanotubes (MWCNTs). Thus, interpenetrated MWCNTs can contribute to increasing the conductivity of $\mathrm{ZnHCF}$ film and holding a large volume changing during cycling, maintaining the electrode structural integrity.

\section{Experimental}

\section{Chemicals}

Potassium hexacyanoferrate (III) $\mathrm{K}_{3}\left[\mathrm{Fe}(\mathrm{CN})_{6}\right](99.0 \%)$ and cyclohexane (99.5\%) were purchased from Applichem Panreac (Barcelona, Spain), $\mathrm{ZnCl}_{2}$ (98.0\%) was purchased from ISOFAR (Duque de Caxias, Brazil) and $\mathrm{HCl}$ $(38.0 \% \mathrm{v} / \mathrm{v})$ was obtained from Reagen (Rio de Janeiro, Brazil), and they were used as received. All solutions were prepared with deionized water obtained from a Milli-Q purification system (Millipore Direct-Q3, Bedford, MA, USA).

MWCNTs $(90.0 \%$, transition metal oxide $<1 \%)$ were purchased from Nanocyl ${ }^{\circledR} \mathrm{NC} 7000^{\mathrm{TM}}$ (Sambreville, Belgium) with an average diameter of $9.5 \mathrm{~nm}$ and an average length of $1.5 \mu \mathrm{m}$ and were used without purification for nanocomposites films preparation.

\section{Synthesis of ZnHCF/MWCNT nanocomposite films}

The preparation of ZnHCF/MWCNTs nanocomposite films was performed according to the liquid-liquid interfacial method. ${ }^{27-33}$ Firstly, $0.15 \mathrm{mg}$ of pristine CNT was dispersed in $20 \mathrm{~mL}$ of cyclohexane using a sonication probe (Cole-Parmer, model CV18) for 10 min (pulses of $50 \mathrm{~s}$ on and $10 \mathrm{~s}$ off) with $35 \%$ amplitude. Then, $10 \mathrm{~mL}$ of
$0.01 \mathrm{~mol} \mathrm{~L}^{-1} \mathrm{ZnCl}_{2}$ and $10 \mathrm{~mL}$ of $0.1 \mathrm{~mol} \mathrm{~L}^{-1} \mathrm{~K}_{3}\left[\mathrm{Fe}(\mathrm{CN})_{6}\right]$ were added into a $50 \mathrm{~mL}$ round bottom flask containing the dispersion of pristine CNT. Then the system was kept under constant agitation for $24 \mathrm{~h}$. A dark yellow transparent film was spontaneously formed at the interface. The ZnHCF/MWCNT film was transferred to a beaker containing the substrate of interest fixed on a copper support. The film was deposited on the substrate surface. Next, the film was maintained in the air atmosphere overnight and dried at $100{ }^{\circ} \mathrm{C}$ for $2 \mathrm{~h}$. The percentage of MWCNT used in this study related to $\mathrm{ZnCl}_{2}$ and $\mathrm{K}_{3}\left[\mathrm{Fe}(\mathrm{CN})_{6}\right]$ was 1.15 and $0.045 \%(\mathrm{~m} / \mathrm{m})$, respectively.

Films containing only ZnHCF have also been prepared according to the procedure described above. Both solutions of precursor reagents were transferred to a $50 \mathrm{~mL}$ round bottom flask with $20 \mathrm{~mL}$ of cyclohexane.

\section{Instrumentation}

The ZnHCF and ZnHCF/MWCNTs film structures were analyzed using an X-ray diffraction (XRD) equipment (Shimadzu XRD 6000, Kyoto, Japan) with a $\mathrm{Cu} \mathrm{K \alpha}$ radiation source $(\lambda=1.5406 \AA)$. The XRD patterns were collected over the $2 \theta$ range of 5 to $80^{\circ}$, at scan rate of $1^{\circ} \mathrm{min}^{-1}$.

Infrared (IR) spectra were obtained using a Frontier Single Range (middle infrared (MIR)) FT-IR spectrophotometer from PerkinElmer (Walthan, USA), in the region between 4000 and $220 \mathrm{~cm}^{-1}$. Samples were analyzed in the solid-state using the attenuated total reflectance (ATR) accessory equipped with diamond crystal.

Raman spectroscopic measurements were carried out using a LabRAM HR Evolution microscope (Horiba, Kyoto, Japan) using a $532 \mathrm{~nm}$ Argon laser over the 200-3500 $\mathrm{cm}^{-1}$ region.

UV-Visible (UV-Vis) spectra of samples were obtained on a Cary5G spectrophotometer (Palo Alto, USA) in the 200-800 nm regions.

Mössbauer spectra were collected with the samples at $298 \mathrm{~K}$ in a conventional transmission spectrometer in the constant acceleration mode and using a ${ }^{57} \mathrm{Co} / \mathrm{Rh}$ gamma-ray source with a nominal activity of about $50 \mathrm{mCi}$, equipped with a transducer (CMTE model MA250) controlled with a linear function driving unit (CMTE model MR351).

Scanning electron microscopy (SEM) images were obtained using a Vega 3 LMU TESCAN (Brno-Kohoutovice, Czech Republic) operated at $20 \mathrm{kV}$. The elemental analysis was achieved using the energy dispersed spectrometer (EDS) model INCA X-ACT (Stanford, Oxford). 


\section{Electrochemical measurements}

The electrochemical characterization was performed with a PGSTAT 12 Autolab potentiostat (Herisau, Switzerland) equipped with a conventional three electrodes cell. Electrochemical impedance spectroscopy (EIS) experiments were carried out using the FRA2 module coupled to the Autolab PGSTAT $128 \mathrm{~N}$ potentiostat (Herisau, Switzerland). Equipment control and data acquisition analyses were also carried out using NOVA 1.11.0 (Metrohm-Autolab, Herisau, Switzerland).

Cyclic voltammetry (CV) measurement and charge and discharge tests were performed using three and two electrodes system. For three electrodes system a platinum wire and $\mathrm{Ag} / \mathrm{AgCl}$ electrode were used as counter and reference electrode, respectively. The $\mathrm{ZnHCF}$ or $\mathrm{ZnHCF} / \mathrm{MWCNT}$ films were used as work electrode. For two electrodes system the ZnHCF or ZnHCF/MWCNT films were utilized as cathode material and a galvanized steel sheet was employed as the anode electrode.

The galvanostatic charge/discharge cycling test of two electrodes system was performed in a potential window ranging from 0.8 to $2.2 \mathrm{~V}$. For the study of rate capability were used the current densities of 5000 to $100 \mathrm{~mA} \mathrm{~g}^{-1}$.
Galvanostatic charge/discharge curves were used to calculate the discharge capacity using the following equation:

$\mathrm{C}=(\mathrm{i} \times \mathrm{t}) / \mathrm{m}$

where $\mathrm{C}$ is the specific capacity $\left(\mathrm{mA} \mathrm{h} \mathrm{g}^{-1}\right), \mathrm{i}$ is the applied current $(\mathrm{mA}), \mathrm{t}$ is the discharge time $(\mathrm{h})$, and $\mathrm{m}$ is the mass of the active material $(\mathrm{g})$. The mass of the materials was obtained by the substrate mass difference before and after the deposition of the films. The coulombic efficiency is given by the discharge/charge time ratio. ${ }^{34}$

\section{Results and Discussion}

\section{Characterization}

Thin films of ZnHCF/MWCNTs and ZnHCF were characterized by XRD, Raman spectroscopy, IR spectroscopy and UV-Vis spectroscopy (Figure 1). The crystal structure of ZnHCF/MWCNTs and ZnHCF were examined by XRD and the patterns are shown in Figure 1a.

The XRD peaks for the $\mathrm{ZnHCF}$ film are well-indexed to $\mathrm{Zn}_{3}{ }^{\mathrm{II}}\left[\mathrm{Fe}^{\mathrm{III}}(\mathrm{CN})_{6}\right]_{2}$ (JCPDS No. 38-0688), adopting a rhombohedral structure (Miller index in blue) belonging to
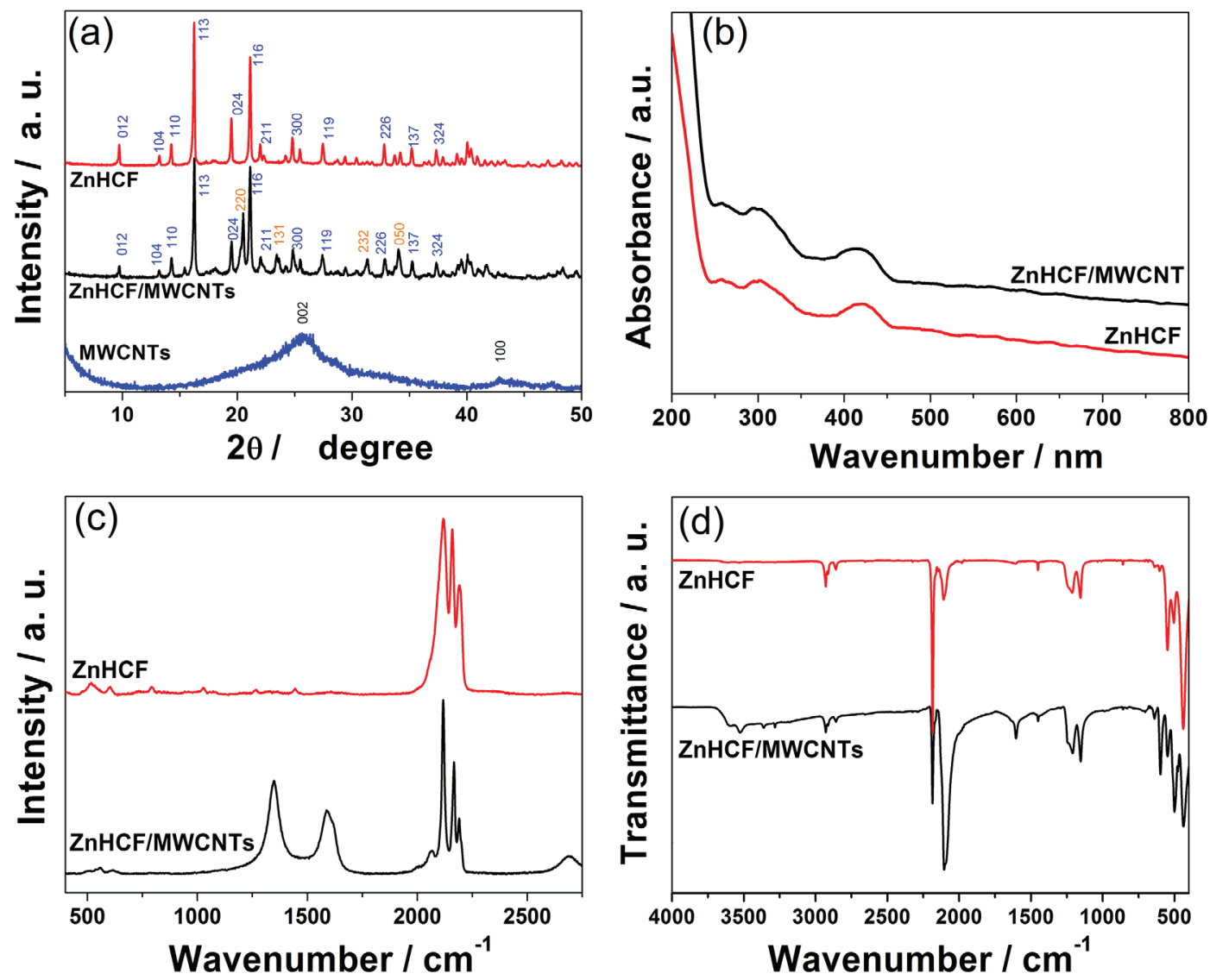

Figure 1. (a) XRD patterns; (b) UV-Vis; (c) Raman and (d) FTIR (ATR) spectra of the hexacyanoferrate films. 
the R-3c space group. ${ }^{21}$ Besides that, for both samples, it is observed the diffraction lines attributed to the orthorhombic phase (Miller index in red), revealing a mixture of phases. . $^{35,36}$ The presence of this additional phase is more pronounced in ZnHCF/MWCNTs sample. The orthorhombic structure belongs to the space group Pbam and is associated with molecular formula $\mathrm{Zn}_{2}{ }^{\mathrm{II}}\left[\mathrm{Fe}^{\mathrm{II}}(\mathrm{CN})_{6}\right] \cdot 2.5 \mathrm{H}_{2} \mathrm{O}$ (JCPDS No. 28-1466). It is important to mention that orthorhombic structure is not common for zinc hexacyanoferrate synthesized using the present method, indicating that MWCNTs act preserving water molecules in ZnHCF sites.

The UV-Vis spectra of the films are displayed in Figure $1 \mathrm{~b} .\left[\mathrm{Fe}(\mathrm{CN})_{6}\right]^{3-}$ has three characteristic absorption bands at 260, 302 and $420 \mathrm{~nm},{ }^{37}$ which are assigned to the ligand-to-metal charge transfer transitions. Besides that, it is observed higher values of absorbance for ZnHCF/MWCNTs film compared with $\mathrm{ZnHCF}$. This feature is related to the stabilization of the film in the aqueous/organic interface occurred when the carbonaceous material is present.

The nanocomposite films were also analyzed by Raman spectroscopy (Figure 1c). The spectra of both samples confirmed the $\mathrm{ZnHCF}$ formation. The characteristic bands of ZnHCF can be observed at 517 and $602 \mathrm{~cm}^{-1}$ (attributed to $\mathrm{Fe}-\mathrm{C}$ stretching), and at 2119,2161 and $2191 \mathrm{~cm}^{-1}$, assigned to $\mathrm{A}_{1 \mathrm{~g}}$ totally symmetrical stretching of $\mathrm{CN} .{ }^{38}$ For $\mathrm{C} \equiv \mathrm{N}$ vibration the two bands at lower wavenumbers (2119 and $2161 \mathrm{~cm}^{-1}$ ) are characteristics of cyanide stretching in reduced octahedrally coordinated iron-cyanide $\left(\mathrm{Fe}^{\mathrm{II}}-\mathrm{CN}\right)$, while the single band at ca. $2191 \mathrm{~cm}^{-1}$ is characteristics of cyanide stretching near oxidized irons $\left(\mathrm{Fe}^{\mathrm{III}}-\mathrm{CN}\right) .^{39,40}$ It is important to note that for ZnHCF/MWCNTs film the relative intensity of the band attributed to $\mathrm{C} \equiv \mathrm{N}$ associated with $\mathrm{Fe}^{3+}$ decreases when compared with $\mathrm{ZnHCF}$ material, suggesting a higher contribution of reduced iron sites in the structure when carbon nanotubes are present,

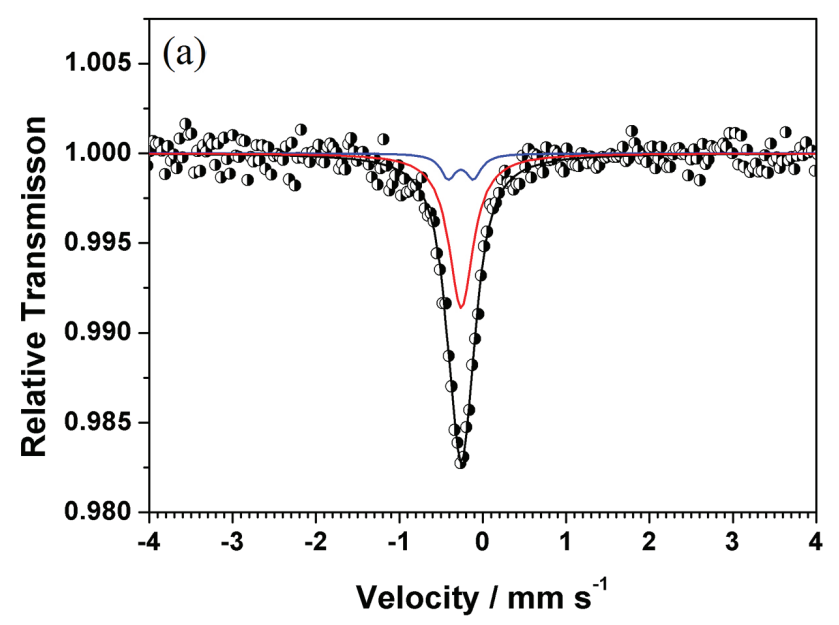

corroborating the XRD results. For the nanocomposite film, three additional bands are also observed at 1349 , 1591 and $2698 \mathrm{~cm}^{-1}$, corresponding to D, G, and 2D bands, respectively. These bands are associated with MWCNTs structure, since $\mathrm{G}$ band corresponds to $\mathrm{E}_{2 \mathrm{~g}}$ symmetry at the center of Brillouin zone, and is assigned to in-plane vibration of $\mathrm{C}=\mathrm{C}$ bond. The $\mathrm{D}$ band is attributed to lattice defects and finite crystal size occurring inside the carbon nanotubes atomic layer, activated by the presence of disorder in carbon systems. Besides, the $2 \mathrm{D}$ band is attributed to the overtone of the D band. ${ }^{41,42}$ Figure 1d shows the IR spectra of ZnHCF and ZnHCF/MWCNTs films. Both spectra show a series of bands referring to stretching and deformation modes of zinc hexacyanoferrate structure. These signals are assigned to the following vibrations: $v(\mathrm{CN})$ at 2184 and $2100 \mathrm{~cm}^{-1}$, $\delta(\mathrm{FeCN})$ at $548 \mathrm{~cm}^{-1}, v\left(\mathrm{Zn}^{\mathrm{II}} \mathrm{N}\right)$ at $492 \mathrm{~cm}^{-1}$, and $v\left(\mathrm{Fe}^{\mathrm{III}} \mathrm{C}\right)$ at $437 \mathrm{~cm}^{-1}$. According to the spectra two important features can be highlighted. The first one is the presence of two signals attributed to $v(\mathrm{OH})$ and $\delta(\mathrm{HOH})$ vibrations, at 3624 and $1608 \mathrm{~cm}^{-1}$, respectively, indicating the presence of water in the structure, and indicating the formation of orthorhombic phase $\left(\mathrm{Zn}_{2}{ }^{\mathrm{II}}\left[\mathrm{Fe}^{\mathrm{II}}(\mathrm{CN})_{6}\right] \cdot 2.5 \mathrm{H}_{2} \mathrm{O}\right)$ for the hexacyanoferrates, especially in the presence of carbon nanotubes. It is also noted that for ZnHCF/MWCNTs occurs a changing in relative intensity of the band attributed to $v(\mathrm{CN})$, also suggesting the presence of an additional phase for the nanocomposite film. ${ }^{20}$ It is also observed the presence of two bands around 1211 and $1149 \mathrm{~cm}^{-1}$ in Fourier transform infrared (FTIR) spectra, which can be associated with $\mathrm{C}-\mathrm{N}$ stretching. ${ }^{43}$

The Mössbauer spectra are shown in Figure 2. All the spectra are composed of a singlet, assigned to $\mathrm{Fe}^{2+}$, and a quadrupole doublet to $\mathrm{Fe}^{3+} .{ }^{44-46}$ The zinc ferrocyanide fraction, in both $\mathrm{Fe}^{2+}$ and $\mathrm{Fe}^{3+}$ presence, was appreciated in the corresponding Mössbauer spectra as a slight asymmetry

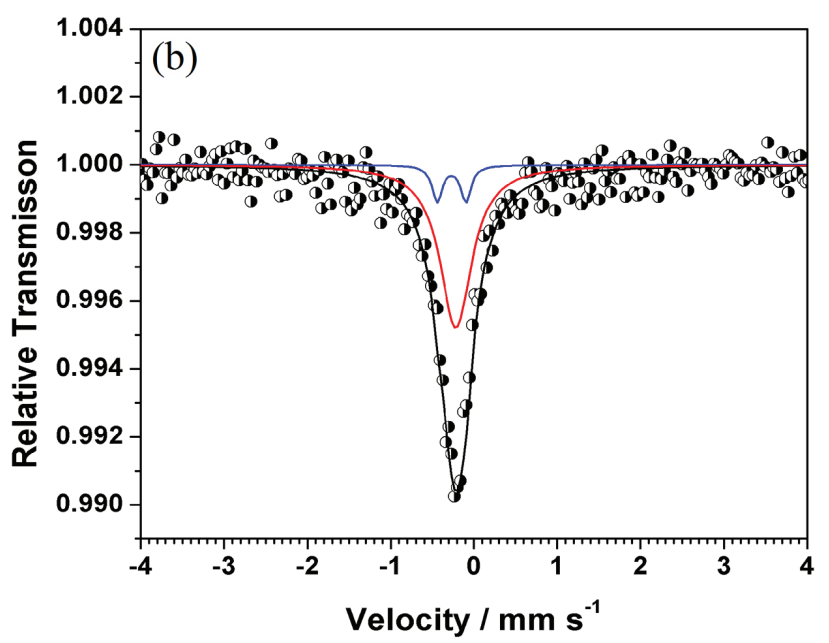

Figure 2. ${ }^{57} \mathrm{Fe}$ Mössbauer spectra for the samples (a) ZnHCF and (b) ZnHCF/MWCNTs at $298 \mathrm{~K}$. 
for the observed quadrupole doublet. Ferric and ferrous species have slightly different isomer deviation values, and this causes this asymmetry. According to signal intensities, this $\mathrm{Fe}^{3+}$ contribution was estimated at about 10 and 5\% of the sample weight for ZnHCF and ZnHCF/MWCNTs, respectively, showing a higher contribution of $\mathrm{Fe}^{2+}$ in the presence of carbonaceous material, which corroborates the previous characterizations.

SEM images were acquired to study the morphology of the films. Figures $3 \mathrm{a}$ and $3 \mathrm{~b}$ for $\mathrm{ZnHCF}$ material reveal particles with irregular to cubic morphology, with an average size ranging from 2 to $10 \mu \mathrm{m}$. ZnHCF/MWCNTs film (Figures 3c, 3d and 3e) also exhibits an irregular/ cubic shape, however, presenting more homogeneous smaller particles, ranging from $500 \mathrm{~nm}$ to $1.0 \mu \mathrm{m}$. Besides, it is possible to observe the interaction between $\mathrm{ZnHCF}$ particles and the MWCNTs. The EDS analysis (Figure S1, Supplementary Information (SI) section) confirms the presence of $\mathrm{Zn}, \mathrm{Fe}, \mathrm{N}, \mathrm{C}$ and $\mathrm{K}$ for both films, these data corroborate with the characterizations discussed above and confirm the success of the synthesis for nanocomposite films.
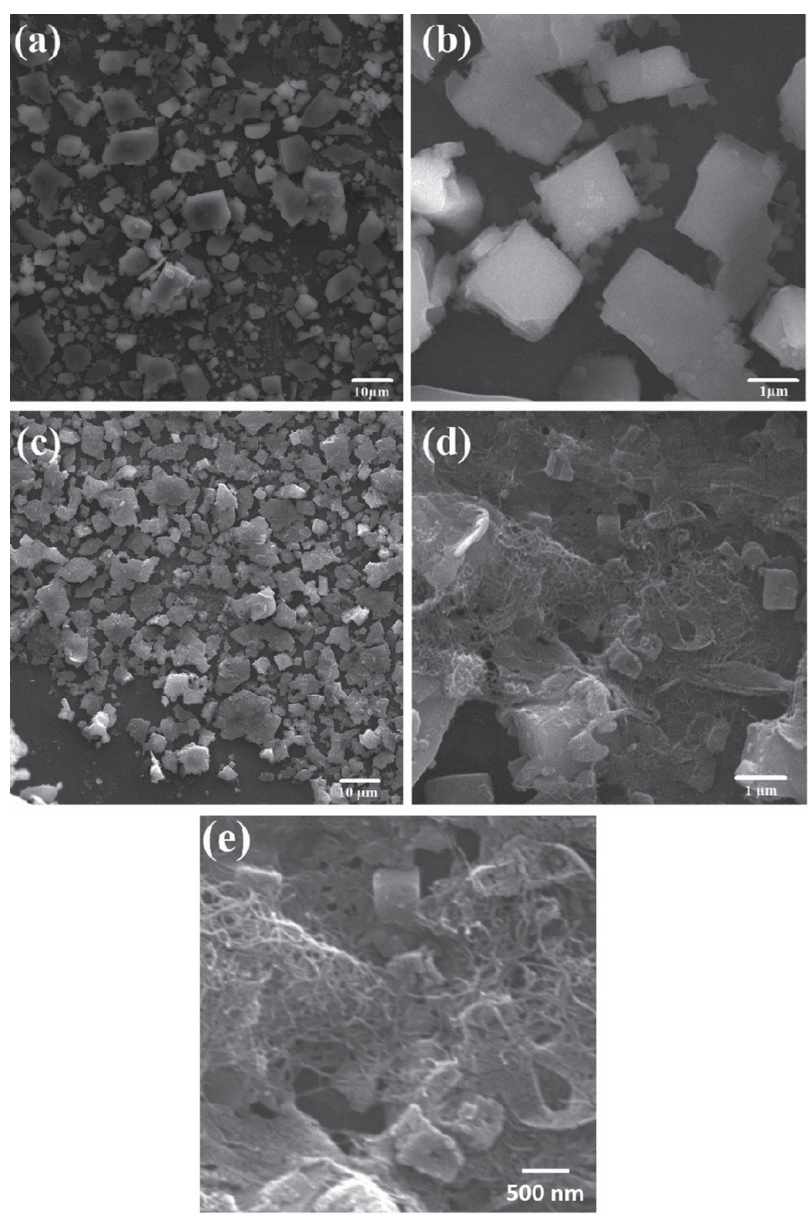

Figure 3. SEM images of the film: (a, b) ZnHCF and (c-e) ZnHCF/ MWCNTs.

\section{Electrochemical study}

Electrochemical measurements were performed in a three-electrode cell containing $1.0 \mathrm{~mol} \mathrm{\textrm {L } ^ { - 1 }} \mathrm{ZnCl}_{2}$ ( $\mathrm{pH}=2$ ), ZnHCF/MWCNTs or ZnHCF films as working electrode, $\mathrm{Ag} / \mathrm{AgCl}$ reference electrode, and a platinum wire as the counter electrode. Figure 4 a shows the cyclic voltammograms for the films at a scan rate of $20 \mathrm{mV} \mathrm{s}^{-1}$, and a potential range of -0.2 to $1.3 \mathrm{~V}$. It can be seen that both films exhibit two redox process attributed to the reversible conversion between $\mathrm{Fe}^{2+}$ and $\mathrm{Fe}^{3+}$ present in octahedral $\left[\mathrm{Fe}(\mathrm{CN})_{6}\right]^{\text {n- }}$ block accompanying the extraction/insertion of $\mathrm{Zn}^{2+}$. In the potential of $0.55 / 0.77 \mathrm{~V}$, the present redox process can be attributed to the reduction and oxidation of iron sites present in zinc hexacyanoferrate structure. The second process in the potential of $0.81 / 0.95 \mathrm{~V}$ can be assigned to the presence of $\mathrm{Zn}_{2}{ }^{\mathrm{II}}\left[\mathrm{Fe}^{\mathrm{II}}(\mathrm{CN})_{6}\right] \cdot 2.5 \mathrm{H}_{2} \mathrm{O}$ structure. It is observed that current intensity for $\mathrm{ZnHCF} / \mathrm{MWCNT}$ film is very higher than observed for $\mathrm{ZnHCF}$ film. This behavior can be associated with the fast and easy insertion of zinc ions into the hexacyanoferrate framework structure, facilitated by the presence of a carbon nanotube network uniformly covering the substrate since a higher density of CNTs can provide a small resistance for the electrode. ${ }^{47}$

Figures $4 \mathrm{~b}$ and $4 \mathrm{c}$ present the discharge capacities of ZnHCF and ZnHCF/MWCNTs films (third cycle), respectively, at different current densities and using a cell with three electrodes. The discharge capacities obtained for ZnHCF/MWCNTs varied from 2.22 to $19.28 \mathrm{~mA} \mathrm{~h} \mathrm{~g}^{-1}$, on the other hand, the $\mathrm{ZnHCF}$ exhibited lower values, ranging from 0.25 to $2.81 \mathrm{~mA} \mathrm{~h} \mathrm{~g}^{-1}$. In addition, the long-term cycling stability and Coulombic efficiency were investigated by a continuous cycling test at $250 \mathrm{~mA} \mathrm{~g}^{-1}$ for 200 cycles. As shown in Figures $4 \mathrm{~d}$ and $4 \mathrm{e}$, the capacity retention was $36.89 \%$, with a coulombic efficiency of $99.58 \%$ for ZnHCF/MWCNTs. O the other hand, ZnHCF films presented capacity retention of $0.87 \%$ and the coulombic efficiency equal to $92.55 \%$. The high values of coulombic efficiency indicate that both films present good reversibility, however, the ZnHCF/MWCNTs films showed better results in terms of cycling stability. Considering the electrochemical data, it is reasonable to deduce that the charge/discharge performance of ZnHCF/MWCNTs is positively correlated with the presence of MWCNTs. Thus, it is assumed that CNT networks facilitate the diffusion of $\mathrm{Zn}^{2+}$ ions in the $\mathrm{ZnHCF}$ structure, providing high discharge rate capability.

Aiming to construct a full two electrodes aqueous zincion battery the $\mathrm{ZnHCF}$ and $\mathrm{ZnHCF} / \mathrm{MWCNT}$ silms were investigated as the cathodes and a zinc plate as the anode. 


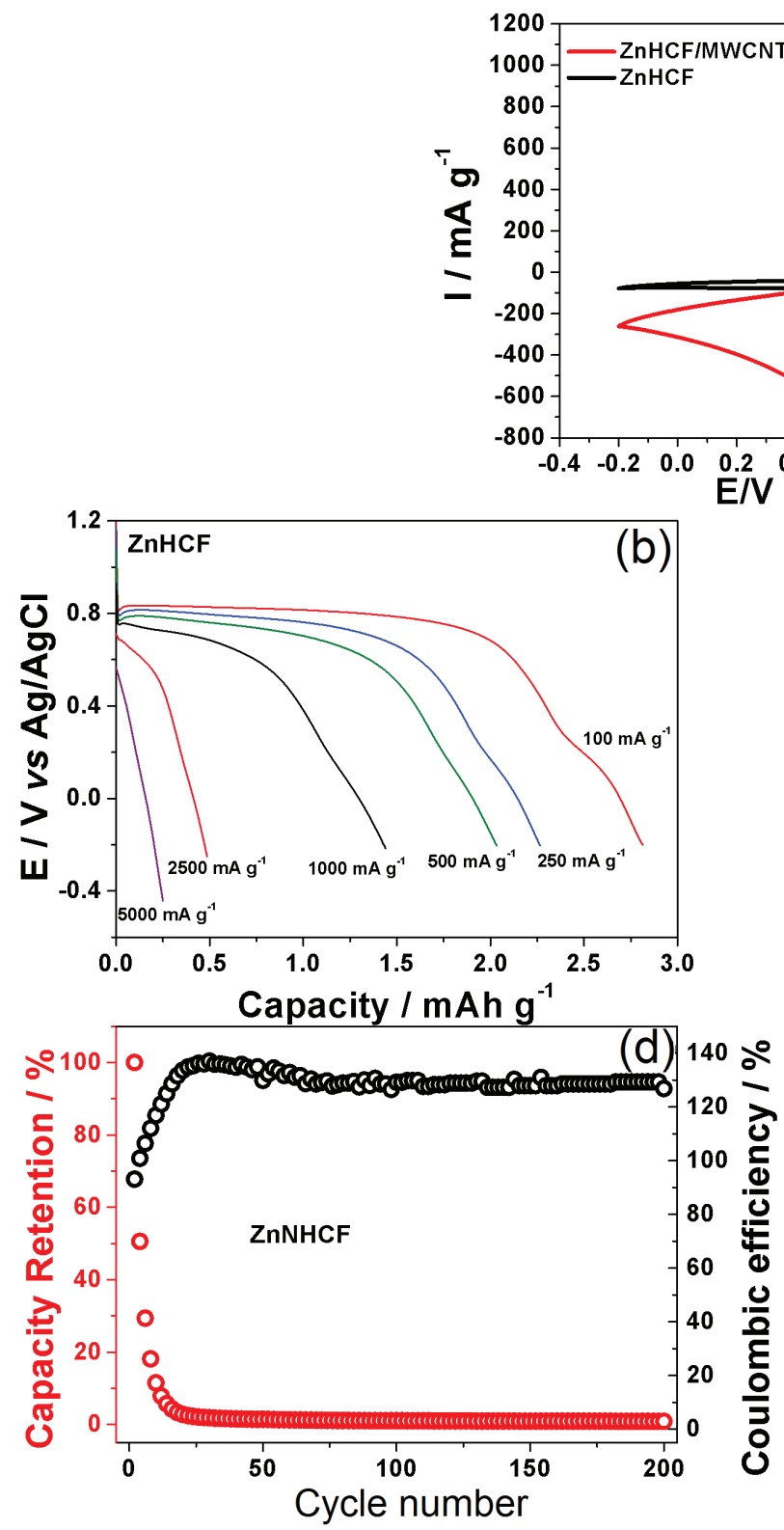

(a)

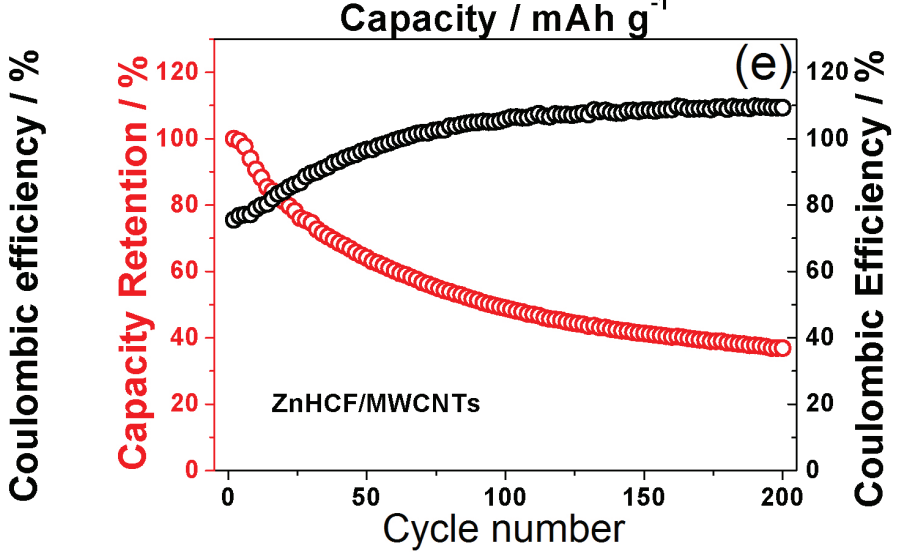

Figure 4. (a) CVs; rate capability at $250 \mathrm{~mA} \mathrm{~g}^{-1}$ of (b) ZnHCF and (c) ZnHCF/MWCNTs films; cycle life test of (d) ZnHCF and (e) ZnHCF/MWCNTs films.

The typical voltammograms of two individual electrodes at a scan rate of $20 \mathrm{mV} \mathrm{s}^{-1}$ are shown in Figure S2 (SI section). The electrochemical performance of a battery relies on the following two electrochemical processes (equations 2 and 3$):^{21}$

Cathode: $\mathrm{Zn}_{3}\left[\mathrm{Fe}(\mathrm{CN})_{6}\right]_{2}+\mathrm{xZn}^{2+}+2 \mathrm{xe}^{-} \rightleftarrows$

$$
\mathrm{Zn}_{3+\mathrm{x}}\left[\mathrm{Fe}(\mathrm{CN})_{6}\right]_{2}
$$

Anode: $\mathrm{xZn} \rightleftarrows \mathrm{xZn}^{2+}+2 \mathrm{xe}^{-} \quad(0 \leq \mathrm{x} \leq 1)$

As shown in Figure S2 (SI section), the redox peaks at around $0.0 \mathrm{~V}\left(v s . \mathrm{Zn} / \mathrm{Zn}^{2+}\right.$ ) for $\mathrm{Zn}$ plate electrode are ascribed to the reversible dissolution/deposition of
$\mathrm{Zn}$, whereas the redox peaks for the $\mathrm{ZnHCF}$ film are located at 1.86/1.55 V and for the ZnHCF/MWCNTs film appear at ca. 1.87 and $1.55 \mathrm{~V} v s . \mathrm{Zn} / \mathrm{Zn}^{2+}$; these, in turn, are related to the insertion/extraction of $\mathrm{Zn}^{2+}$ in the structure of ZnHCF. The zinc ion battery (ZIB) containing ZnHCF/MWCNTs as cathode material shows good rate capability, achieving a capacity of $25.81 \mathrm{~mA} \mathrm{~h} \mathrm{~g}^{-1}$, with capacity retention and coulombic efficiency values of 55.77 and $100 \%$, respectively (Figure 5). These results reveal good reversibility and a significant improvement in the values of capacity retention compared to the three-electrode system. In contrast, the $\mathrm{ZnHCF}$ film showed no improvement in electrochemical performance when used as cathodic material in ZIB, presenting a capacity of $3.28 \mathrm{~mA} \mathrm{~h} \mathrm{~g}^{-1}$, 

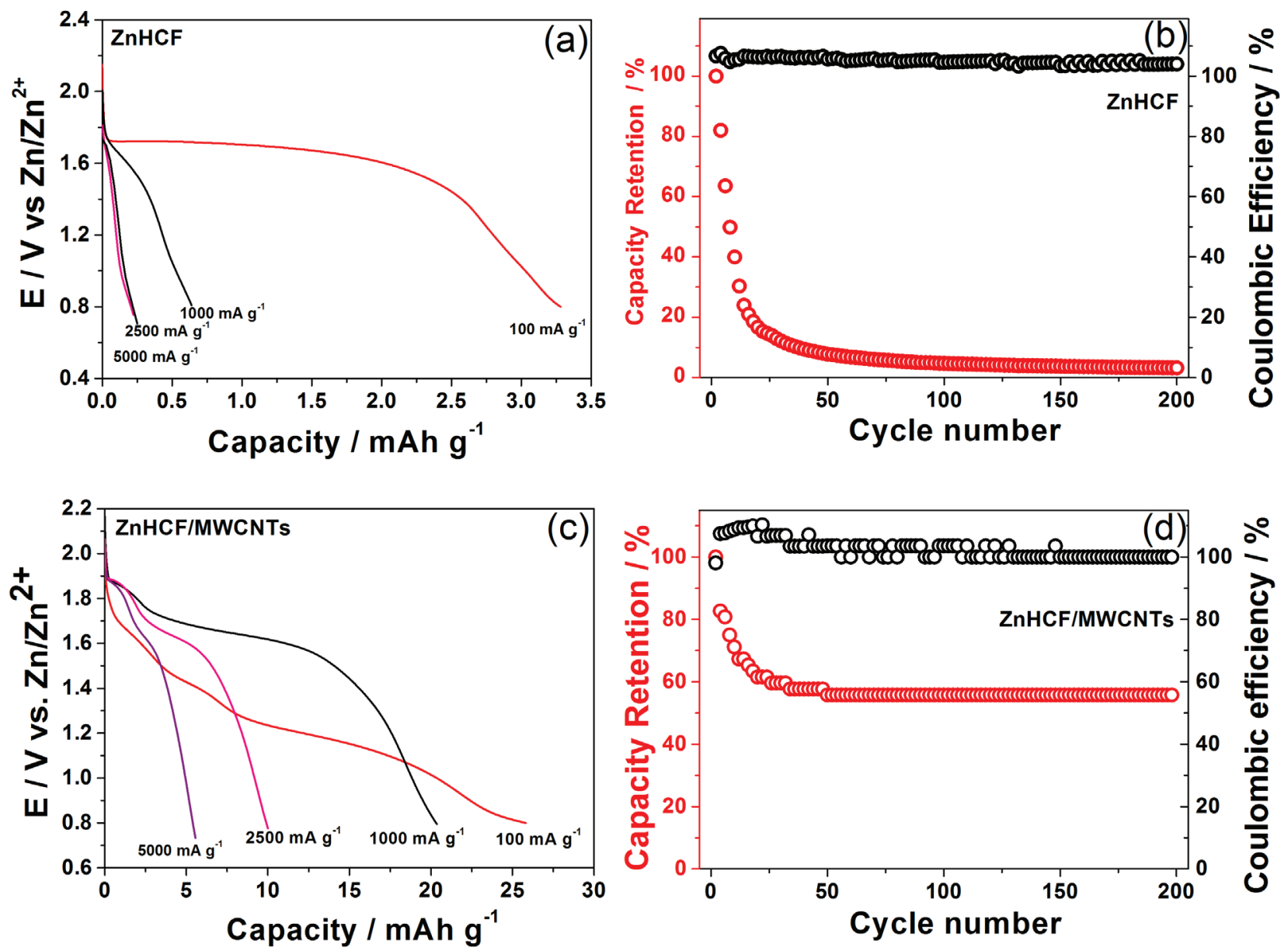

Figure 5. Rate capability of battery: (a) ZnHCF and (c) ZnHCF/MWCNTs; cycle life test of (b) ZnHCF and (d) ZnHCF/MWCNTs films at rate of $250 \mathrm{~mA} \mathrm{~g}{ }^{-1}$.

with capacity retention and coulombic efficiency values of 3.21 and $100 \%$, respectively (Figures $5 a-5 b$ ).

Despite the electrochemical performance of aqueous zinc-ion battery based in ZnHCF/MWCNTs films is below the other aqueous metal-ions batteries as shown in Table 1, the good reversibility, high potential difference and physics characteristics of the material prepared in this work make it possible to manufacture transparent and lightweight storage devices in the film form, besides that, our battery become a low-cost, safe, and environmentally friendly alternative to traditional technology. ${ }^{51-53}$ In addition, the
ZnHCF/MWCNTs film as cathode presents superior electrochemical properties compared with $\mathrm{ZnHCF}$ film, especially due MWCNTs network, which contributes to enhancing conductivity inside and between $\mathrm{ZnHCF}$ particles, favoring the electrode structural integrity.

\section{Conclusions}

In summary, we investigated structural, spectroscopic, morphological and electrochemical properties of the $\mathrm{ZnHCF}$ and $\mathrm{ZnHCF} / \mathrm{MWCNT}$ thin films prepared by

Table 1. Comparison of the cathode performance for $\mathrm{Zn}$ ion batteries based on PBAs

\begin{tabular}{lccccc}
\hline Cathode & Electrode form & Electrolyte & Capacity / $\left(\mathrm{mA} \mathrm{h} \mathrm{g}^{-1}\right)$ & Cycling stability/cycles $^{\mathrm{a}}$ & Reference \\
\hline $\mathrm{NiHCF}$ & slurry & aqueous & 76.2 & $81 \% / 1000\left(500 \mathrm{~mA} \mathrm{~g}^{-1}\right)$ & 7 \\
$\mathrm{CuHCF}$ & slurry & aqueous & 56 & $96.3 \% / 100\left(60 \mathrm{~mA} \mathrm{~g}^{-1}\right)$ & 48 \\
$\mathrm{ZnHCF}$ & slurry & aqueous & 65.4 & $81 \% / 100\left(300 \mathrm{~mA} \mathrm{~g}^{-1}\right)$ & 21 \\
$\mathrm{FeHCF}$ & slurry & aqueous & 120 & $30 \% / 50\left(10 \mathrm{~mA} \mathrm{~g}^{-1}\right)$ & 49 \\
$\mathrm{NiHCF}$ & powder & organic & 55.6 & $90 \% / 35(0.2 \mathrm{C})$ & 50 \\
ZnHCF/MWCNTs & film & aqueous & 25.81 & $56 \% / 200\left(250 \mathrm{~mA} \mathrm{~g}^{-1}\right)$ & this work \\
\hline
\end{tabular}

HCF: hexacyanoferrate; MWCNT: multi-walled carbon nanotube. ${ }^{\mathrm{a}}$ Cycling stability/cycles according to specific current (in parentheses). 
the interfacial method. This nanocomposite was used as a cathode material for rechargeable aqueous zinc ion battery. The results demonstrated the presence of MWCNTs improves and extends the properties of $\mathrm{ZnHCF}$, in addition to influencing the structure and morphology of the hexacyanoferrate particles. In a general analysis, the results presented the $\mathrm{ZnHCF} / \mathrm{MWCNTs}$ thin films cathode is highly reversible in $\mathrm{ZnCl}_{2}$ aqueous electrolyte with $\mathrm{Zn}$ anode. This aqueous rechargeable zinc-ion battery based on ZnHCF/MWCNTs thin film as cathode exhibits a rate capability and capacity retention of $55.77 \%$ after 200 cycles, values much higher than those obtained for ZnHCF single component. The present work may provide a new alternative related to storage devices, achieving transparency and lightweight.

\section{Supplementary Information}

Supplementary data are available free of charge at http://jbcs.sbq.org.br as PDF file.

\section{Acknowledgments}

The authors are grateful to CAPES, FAPEMIG, FINEP, and CNPq (406529/2016-7 and 304958/2017-4) for financial support. Grupo de Materiais Inorgânicos do Triângulo (GMIT) research group was supported by FAPEMIG (APQ-00330-14). This work was partially supported by the Brazilian Institute of Science and Technology (INCT) in Carbon Nanomaterials. We also thank to multiuser laboratory of Chemistry Institute at the University Federal Uberlândia for providing the equipment and technical support for experiments involving scanning electron microscopy, EDS and XRD.

\section{References}

1. Itaya, K.; Uchida, I.; Neff, V. D.; Acc. Chem. Res. 1986, 19, 162.

2. Nie, P.; Shen, L.; Luo, H.; Ding, B.; Xu, G.; Wang, J.; Zhang, X.; J. Mater. Chem. A 2014, 2, 5852.

3. Shores, M. P.; Beauvais, L. G.; Long, J. R.; J. Am. Chem. Soc. 1999, 121, 775 .

4. Kaye, S. S.; Long, J. R.; J. Am. Chem. Soc. 2005, 127, 6506.

5. Kaye, S. S.; Long, J. R.; Catal. Today 2007, 120, 311.

6. Natesakhawat, S.; Culp, J. T.; Matranga, C.; Bockrath, B.; J. Phys. Chem. C 2007, 111, 1055.

7. Lu, K.; Song, B.; Zhang, J.; Ma, H.; J. Power Sources 2016, 321, 257.

8. Niu, L.; Chen, L.; Zhang, J.; Jiang, P.; Liu, Z.; J. Power Sources 2018, 380, 135.
9. Wessells, C. D.; Huggins, R. A.; Cui, Y.; Nat. Commun. 2011, 2, 550 .

10. Kumar, S. S.; Joseph, J.; Phani, K. L.; Chem. Mater. 2007, 19, 4722.

11. Qiu, J.-D.; Peng, H.-Z.; Liang, R.-P.; Li, J.; Xia, X.-H.; Langmuir 2007, 23, 2133.

12. Zhao, G.; Feng, J.-J.; Zhang, Q.-L.; Li, S.-P.; Chen, H.-Y.; Chem. Mater. 2005, 17, 3154.

13. Thallapally, P. K.; Motkuri, R. K.; Fernandez, C. A.; McGrail, B. P.; Behrooz, G. S.; Inorg. Chem. 2010, 49, 4909.

14. Lian, H.-Y.; Hu, M.; Liu, C.-H.; Yamauchi, Y.; Wu, K. C. W.; Chem. Commun. 2012, 48, 5151.

15. Roy, X.; Hui, J. K. H.; Rabnawaz, M.; Liu, G.; MacLachlan, M. J.; J. Am. Chem. Soc. 2011, 133, 8420.

16. Shokouhimehr, M.; Soehnlen, E. S.; Hao, J.; Griswold, M.; Flask, C.; Fan, X.; Basilion, J. P.; Basu, S.; Huang, S. D.; J. Mater. Chem. 2010, 20, 5251.

17. Li, J.; Qiu, J. D.; Xu, J. J.; Chen, H. Y.; Xia, X. H.; Adv. Funct. Mater. 2007, 17, 1574.

18. Torad, N. L.; Hu, M.; Imura, M.; Naito, M.; Yamauchi, Y.; J. Mater. Chem. 2012, 22, 18261.

19. Zakaria, M. B.; Chikyow, T.; Coord. Chem. Rev. 2017, 352, 328.

20. Rodríguez-Hernández, J.; Reguera, E.; Lima, E.; Balmaseda, J.; Martínez-García, R.; Yee-Madeira, H.; J. Phys. Chem. Solids 2007, 68, 1630.

21. Zhang, L.; Chen, L.; Zhou, X.; Liu, Z.; Adv. Energy Mater. 2015, 5, 1400930.

22. Zhang, L.; Chen, L.; Zhou, X.; Liu, Z.; Sci. Rep. 2015, 5, 18263.

23. Lee, S. W.; Yabuuchi, N.; Gallant, B. M.; Chen, S.; Kim, B.-S.; Hammond, P. T.; Shao-Horn, Y.; Nat. Nanotechnol. 2010, 5, 531.

24. Nossol, E.; Zarbin, A. J. G.; J. Mater. Chem. 2012, 22, 1824.

25. Samantha, H.; Zarbin, A. J. G.; Chem. - Eur. J. 2016, $22,6643$.

26. Seungki, H.; Jongsu, L.; Kyungsik, D.; Minbaek, L.; Hoon, K. J.; Sangkyu, L.; Dae-Hyeong, K.; Adv. Funct. Mater. 2017, 27, 1704353.

27. de Souza, V. H. R.; Oliveira, M. M.; Zarbin, A. J. G.; J. Power Sources 2014, 260, 34.

28. Nossol, E.; Souza, V. H. R.; Zarbin, A. J. G.; J. Colloid Interface Sci. 2016, 478, 107.

29. Salvatierra, R. V.; Domingues, S. H.; Oliveira, M. M.; Zarbin, A. J. G.; Carbon 2013, 57, 410.

30. Salvatierra, R. V.; Oliveira, M. M.; Zarbin, A. J. G.; Chem. Mater. 2010, 22, 5222.

31. Souza, V. H. R.; Husmann, S.; Neiva, E. G. C.; Lisboa, F. S.; Lopes, L. C.; Salvatierra, R. V.; Zarbin, A. J. G.; Electrochim. Acta 2016, 197, 200.

32. Castro, S. V. F.; Silva, M. N. T.; Tormin, T. F.; Santana, M. H. P.; Nossol, E.; Richter, E. M.; Munoz, R. A. A.; Anal. Chim. Acta 2018, 1035, 14. 
33. Rocha, D. P.; Silva, M. N. T.; Cardoso, R. M.; Castro, S. V. F.; Tormin, T. F.; Richter, E. M.; Nossol, E.; Munoz, R. A. A.; Sens. Actuators, B 2018, 269, 293.

34. Xu, C.; Li, B.; Du, H.; Kang, F.; Angew. Chem., Int. Ed. 2012, $51,933$.

35. Cola, M.; Valentini, M. T. G.; Inorg. Chem. Lett. 1972, 8, 5.

36. Denisova, T. A.; Maksimova, L. G.; Leonidova, O. N.; Melkozerova, M. A.; Zhuravlev, N. A.; Polyakov, E. V.; Russ. J. Inorg. Chem. 2009, 54, 649.

37. Alexander, J. J.; Gray, H. B.; J. Am. Chem. Soc. 1968, 90, 4260.

38. Coupry, C.; Lautié, A.; Revault, M.; Dufilho, J.; J. Raman Spectrosc. 1994, 25, 89.

39. Steen, W. A.; Jeerage, K. M.; Schwartz, D. T.; Appl. Spectrosc. 2002, 56, 1021.

40. Nakamoto, K.; Infrared and Raman Spectra of Inorganic and Coordination Compounds, Part B, $6^{\text {th }}$ ed.; John Wiley \& Sons, Inc.: Hoboken, 2009.

41. Bokobza, L.; Zhang, J.; Express Polym. Lett. 2012, 6, 601.

42. Delhaes, P.; Couzi, M.; Trinquecoste, M.; Dentzer, J.; Hamidou, H.; Vix-Guterl, C.; Carbon 2006, 44, 3005.

43. Donald, L.; Pavia, G. M. L.; Kriz, G. S.; Vyvyan, J. R.; Introduction to Spectroscopy, $4^{\text {th }}$ ed.; Brooks/Cole, Cengage Learning: Belmont, 2001.

44. Mizuno, Y.; Okubo, M.; Hosono, E.; Kudo, T.; Oh-ishi, K.; Okazawa, A.; Kojima, N.; Kurono, R.; Nishimura, S.-i.; Yamada, A.; J. Mater. Chem. A 2013, 1, 13055.
45. Ojwang, D. O.; Grins, J.; Wardecki, D.; Valvo, M.; Renman, V.; Häggström, L.; Ericsson, T.; Gustafsson, T.; Mahmoud, A.; Hermann, R. P.; Svensson, G.; Inorg. Chem. 2016, 55, 5924.

46. Gawali-Salunke, S.; Varret, F.; Maurin, I.; Enachescu, C.; Malarova, M.; Boukheddaden, K.; Codjovi, E.; Tokoro, H.; Ohkoshi, S.; Hashimoto, K.; J. Phys. Chem. B 2005, 109, 8251.

47. Sarker, B. K.; Shekhar, S.; Khondaker, S. I.; ACS Nano 2011, 5, 6297.

48. Trócoli, R.; La Mantia, F.; ChemSusChem 2015, 8, 481.

49. Liu, Z.; Pulletikurthi, G.; Endres, F.; ACS Appl. Mater. Interfaces 2016, 8, 12158.

50. Chae, M. S.; Heo, J. W.; Kwak, H. H.; Lee, H.; Hong, S.-T.; J. Power Sources 2017, 337, 204.

51. Liu, R.; Li, D.; Wang, C.; Li, N.; Li, Q.; Lü, X.; Spendelow, J. S.; Wu, G.; Nano Energy 2014, 6, 73.

52. Lv, C.; Yang, X.; Umar, A.; Xia, Y.; Jia, Y.; Shang, L.; Zhang, T.; Yang, D.; J. Mater. Chem. A 2015, 3, 22708.

53. Myung, S.-T.; Maglia, F.; Park, K.-J.; Yoon, C. S.; Lamp, P.; Kim, S.-J.; Sun, Y.-K.; ACS Energy Lett. 2017, 2, 196.

Submitted: December 2, 2019

Published online: April 7, 2020 